\title{
Cytotoxicity and radiosensitizing effect of wogonin, an extract from Scutellaria litwinowii, in head and neck squamous cell carcinoma line HN5
}

\author{
Zahra Nariman Asli ${ }^{1}$, Mahnaz Nourbakhsh ${ }^{2}$, Seyed Hadi Mousavi ${ }^{3,4}$, Solmaz Pourgonabadi ${ }^{5,6}$, Azar Fanipakdel $^{7}$
}

${ }^{1}$ M.Sc. in Biophysics, Department of Biochemistry and Biophysics, Faculty of Sciences, Mashhad Branch, Islamic Azad University, Mashhad, Iran

${ }^{2}$ Pharm.D., PhD., Pharmaceutical Biotechnology Specialist, Cancer Research Center, Mashhad University of Medical Sciences, Mashhad, Iran

${ }^{3}$ M.D., PhD. Associate Professor, Medical Toxicology Research Center, Mashhad University of Medical Sciences, Mashhad, Iran

${ }^{4}$ Department of Pharmacology and Pharmacological Research Center of Medicinal Plants, School of Medicine, Mashhad University of Medical Sciences, Mashhad, Iran

${ }^{5}$ Oral and Maxillofacial Surgery Department, Mashhad Dental School, Mashhad University of Medical Sciences, Mashhad, Iran

${ }^{6}$ Dental Research Center, Mashhad University of Medical Sciences, Mashhad, Iran

${ }^{7}$ M.D., Associate Professor of Radiation Oncology, Cancer Research Center, Mashhad University of Medical Sciences, Mashhad, Iran

\section{Type of article: Original}

\begin{abstract}
Background: Radiotherapy is one of the most prominent techniques used in cancer therapy. However, efforts for finding new effective radiosensitizers in improvement of radiotherapy efficacy have been continued yet. Wogonin is a natural flavonoid from Scutellaria litwinowii with known cytotoxic effects in some cancer cells.

Objective: To determine the potential of radiosensitizer effects of wogonin in a head and neck cancer cell line (HN5).

Methods: This study was carried out in Omid Hospital and Herbal Medicine Research Center (Mashhad, Iran). HN5 cells were cultured in DMEM medium and incubated with different concentrations of wogonin (25-500 $\mu \mathrm{g} / \mathrm{ml})$ and were exposed to (2-10 Gray [Gy]) $\gamma$-rays. Cell viability was quantified by MTT assay in wogonin cytotoxicity assay after 24,48 and 72 hours and in coincident radiation and wogonin therapy after 72 hours. Data were analyzed by performing one-way ANOVA in SPSS (V.16). P-value $\leq 0.05$ was considered significant.

Results: Wogonin decreased cell viability in HN5 cells as a time- and concentration-dependent manner. Wogonin could also enhance radiation-induced toxicity. For instance, while cell viability percentage in separate administration of wogonin $(100 \mu \mathrm{M})$ and radiation $(2 \mathrm{~Gy})$ was significantly decreased to $53.98 \pm 2.76$ and $74.97 \pm 1.05$ respectively $(\mathrm{p}<0.001$ ), wogonin $100 \mu \mathrm{M}$ concurrent with 2 Gy radiation decreased the percentage of cell viability to $33.29 \pm 1.76(\mathrm{p}<0.001)$.

Conclusion: Concurrent use of wogonin and radiation increased radiation sensitivity and cell death in HN5 cells. Therefore, wogonin is a good radiosensitizer candidate for more study.

Keywords: Cytotoxicity; HN5 cell line; Radiosensitizing; Squamous cell of head and neck; Wogonin
\end{abstract}

\section{Corresponding author:}

Associate Professor Dr. Azar Fanipakdel, Cancer Research Center, Mashhad University of Medical Sciences, Mashhad, Iran. Tel: +98.5138461518, Email: Fanipa@mums.ac.ir and fanipakdela@gmail.com

Received: July 18, 2017, Accepted: May 05, 2018, Published: November 2018

iThenticate screening: March 07, 2018, English editing: September 15, 2018, Quality control: October 06, 2018

This article has been reviewed / commented by four experts

Funding / research project approval: Mashhad University of Medical Sciences (Grant number: 920003)

Ethics approval: IR.MUMS.REC.1392.95

(C) 2018 The Authors. This is an open access article under the terms of the Creative Commons Attribution-NonCommercialNoDerivs License, which permits use and distribution in any medium, provided the original work is properly cited, the use is non-commercial and no modifications or adaptations are made. 


\section{Introduction}

Head and neck cancer is the sixth most common cancer in the world (1). This cancer accounted for about 4.9 percent of all cancers in the world in 2012. Between 2003 and 2009, 25,925 cases of Head and neck cancer have been recorded in Iran. Trend of age-standardized rate of head and neck cancer in Iran increased from 4.8 cases per 100,000 in 2003 to 7.4 in 2009 (2). Head and neck squamous cell carcinomas (HNSCC) are the most common subtypes of cancers emanated from this region. SCCs are about $90 \%$ of head and neck tumors (3). Chemoradiotherapy is the standard treatment of head and neck cancer (4). Chemotherapy as a systemic treatment for cancer has side effects in normal tissues and suffers from short-term efficacy because of its drug resistance (5). Radiotherapy is regarded as one of the most important therapeutic methods for tumor treatment. This field is undergoing rapid improvement nowadays. Scientists attempt to enhance the sensitization of tumor cells and protection of normal cells with the use of radiosensitizers and radioprotective agents, respectively (6). Large numbers of natural compounds have shown cytotoxic effects in a variety of cancers either alone or in combination with radiation. Wogonin (5, 7-dihydroxy-8-methoxyflavone), a flavonoid-like chemical compound from Scutellaria roots, is one of these herbal components that has been demonstrated to induce apoptosis in different cancer cells and has anti-tumor activity (7-11). For example, anticancer activity of wogonin has been reported in various cancers, such as: leukemia (8), lung (9), prostate (12), breast (11) and Hela cell lines (13). The antitumor functions of these flavones are largely due to their ability to scavenge oxidative radicals (8). Furthermore, It has been mentioned that concurrent use of herbal antioxidants and radiotherapy, increases radiosensitivity in tumor cells (14). Base on wogonin antioxidant and anti- tumoral activities (15), in the present study, we investigated cytotoxic and radiation sensitizer effects of wogonin in head and neck cancer cell lines.

\section{Material and Methods}

This study was carried out in Omid Hospital and Herbal Medicine Research Center (Mashhad, Iran) in 2014, after the ethics committee of Mashhad University of Medical Sciences approved the ethics of the research (IR.MUMS.REC.1392.95).

\subsection{Wogonin}

Collection, extraction, isolation and purification of wogonin from Scutellaria litwinowii roots were carried out as described previously (13). Nuclear magnetic resonance (NMR) spectra were recorded on a Bruker Avance 500 at 25 ${ }^{\circ} \mathrm{C}$ using deuterated chloroform (CDCL3) as a solvent and tetramethylsilane (TMS) as an internal standard (13).

\subsection{Reagents and chemicals}

3-(4,5-dimethylthiazol-2-yl)-2,5-diphenyl tetrazolium bromide (MTT), dimethyl sulfoxide (DMSO) and Triton X100 were purchased from sigma chemical company (St. Louis, MO, USA). Dulbecco's Modified Eagle Medium (DMEM) and fetal bovine serum (FBS) were purchased from Gibco (Grand Island, NY) and

\subsection{Cells and Cell culture}

A human squamous cell carcinomas cell line, HN5 (Pasteur Institute, Tehran, Iran), was cultured in DMEM containing $10 \%$ fetal bovine serum (FBS) and $1 \%$ streptomycin and penicillin antibiotic. HN5 cells were grown in monolayers in $25-\mathrm{cm}^{2}$ flasks and were preserved in a humidified $5 \% \mathrm{CO}_{2}$ and $95 \%$ air atmosphere at $37^{\circ} \mathrm{C}$.

\subsection{Irradiation}

The cultured cells were exposed to $2-10$ Gy doses of $\gamma$ radiation from a Cobalt 60 unit (Theraton 780, Canada). The dose rate was 120 centigray (CGy)/min. Distance from source (SSD) was $80 \mathrm{~cm}$. Field size was $9 \times 5 \mathrm{~cm}^{2}$.

\subsection{Determination of cytotoxicity of wogonin on $\mathrm{HN} 5$ cells}

The cell viability of cultured cells was determined by MTT reduction assay. In brief, HN5 cells were cultured at an initial density of 5000 cells/well on flat-bottomed 96-well culture plates and allowed to grow for 24 hours followed by treatment with wogonin $(25-500 \mu \mathrm{M})$. After passing the desired time $(24 \mathrm{~h}, 48 \mathrm{~h}, 72 \mathrm{~h})$ the medium was removed and cells were labeled with MTT solution $(5 \mathrm{mg} / \mathrm{ml}$ in PBS) for 4 hours. The resulting formazan product was solubilized with DMSO $(100 \mu \mathrm{l})$. Absorbance was measured at $570 \mathrm{~nm}(620 \mathrm{~nm}$ as a reference) in an ELISA reader (16).

\subsection{Determination of cytotoxicity of wogonin in combination with radiation}

At the first step, the effect of continuance or elimination of wogonin during radiotherapy was determined. For this purpose, two groups of HN5 cells were incubated with various concentrations of wogonin $(25-500 \mu \mathrm{M})$ in 96 well 
plates for $48 \mathrm{~h}$. Then after wogonin elimination in one group, both groups received a 2 Gy radiation dose. Cell viability was determined by MTT method after $66 \mathrm{~h}$, letting irradiated cells enter cell cycle and complete apoptosis. At the next step, for determination of cytotoxicity of wogonin in combination with different doses of radiation, HN5 cells pretreated with wogonin $(100 \mu \mathrm{M})$ for $6 \mathrm{~h}$, without any wogonin elimination, were irradiated with $\gamma$-rays during exponential cell growth in 96 well plates using a Cobalt-60 unit with five doses (2-10 Gy) of $\gamma$-rays (17). Cell viability was evaluated 66 hours after radiation by MTT test (18). In both experiments, the control group did not receive any radiation. Cells were kept in DMEM with 10\% FBS and 1\% streptomycin and penicillin antibiotic during all $\gamma$-ray exposures.

\subsection{Statistical analysis}

Data were expressed as mean \pm SEM (standard error of mean). The test was performed using one-way ANOVA followed by a Bonferroni test for several comparisons in SPSS 16 (SPSS Inc., Chicago, Illinois, USA). A probability level of $\mathrm{p}<0.05$ was considered statistically significant.

\section{Results}

\subsection{Cytotoxicity of wogonin on HN5 cells}

For determination of wogonin cytotoxicity, HN5 cells were incubated with various concentrations of wogonin (25$500 \mu \mathrm{M}$ ) for 24,48 and 72 hours (Table 1). The results displayed that wogonin could decline cell viability in HN5 malignant cells in a time- and concentration-dependent manner (Figure 1). Wogonin concentration of $50 \mu \mathrm{M}$ could reduce cell viability after 48 and 72 hours significantly $(\mathrm{p}<0.05)$, while higher doses of 100-500 $\mu \mathrm{M}$ reduced cell viability at all times significantly (Up to $75 \%$ cell death). Morphological changes of HN5 cells after treatment with different concentrations of wogonin confirm the results of the MTT assay (Figure 2).

Table 1. Cytotoxic effect of wogonin on NH5 cells

\begin{tabular}{|l|l|l|l|}
\hline \multirow{2}{*}{ Wogonin concentration } & \%Cell viability after 24 $\mathrm{h}$ & \%Cell viability after 48 $\mathrm{h}$ & \%Cell viability after 72h \\
\cline { 2 - 4 } & Mean \pm SEM & Mean \pm SEM & Mean \pm SEM \\
\hline Control & $100.00 \pm 0.00$ & $100.00 \pm 0.00$ & $100.00 \pm 0.00$ \\
\hline $25 \mu \mathrm{M}$ & $92.11 \pm 3.18$ & $86.21 \pm 5.73$ & $75.28 \pm 7.24$ \\
\hline $50 \mu \mathrm{M}$ & $87.40 \pm 2.84$ & $69.33 \pm 4.42$ & $69.67 \pm 4.43$ \\
\hline $100 \mu \mathrm{M}$ & $71.73 \pm 2.47$ & $66.84 \pm 4.46$ & $53.99 \pm 2.76$ \\
\hline $500 \mu \mathrm{M}$ & $52.43 \pm 0.79$ & $37.02 \pm 1.76$ & $24.77 \pm 1.36$ \\
\hline
\end{tabular}

SEM: Standard Error of Mean

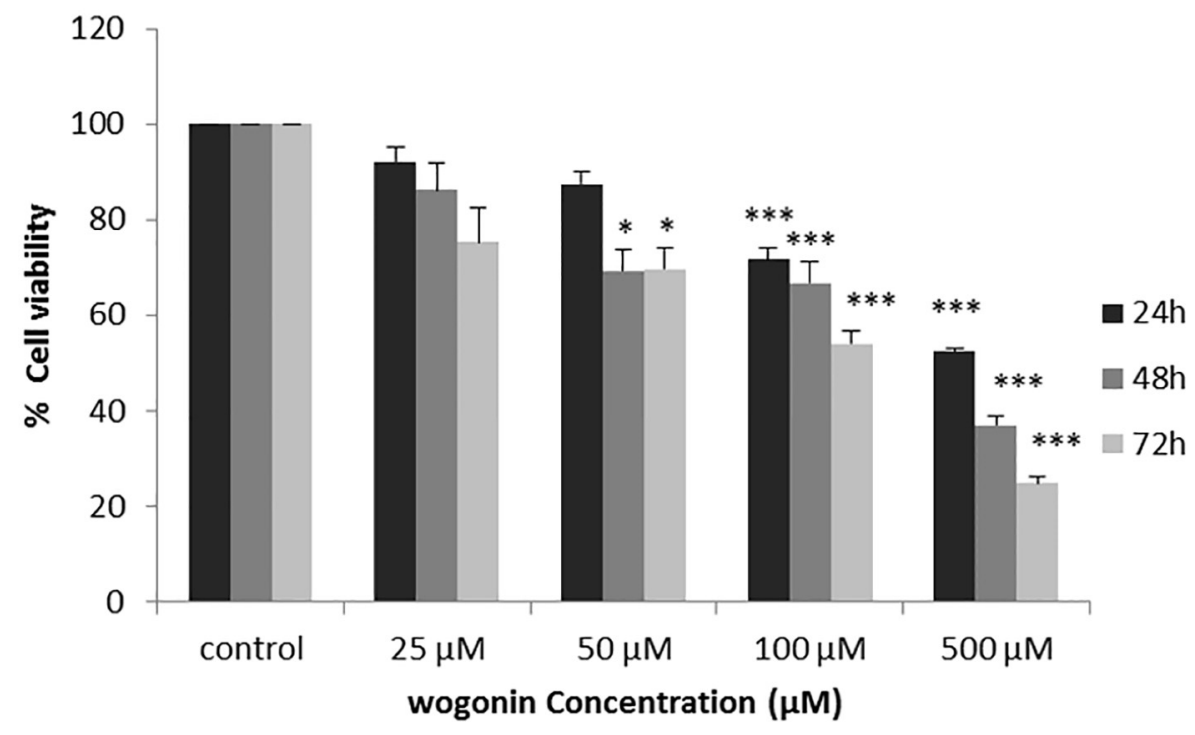

Figure 1. Wogonin cytotoxicity on HN5 cells. HN5 cells were incubated with various concentrations of wogonin $(25-500 \mu \mathrm{M})$ for 24,48 and 72 hours. After these times, the cell viability was determined by MTT assay; ${ }^{*} \mathrm{p}<0.05$, $* * * \mathrm{p}<0.001)$ 

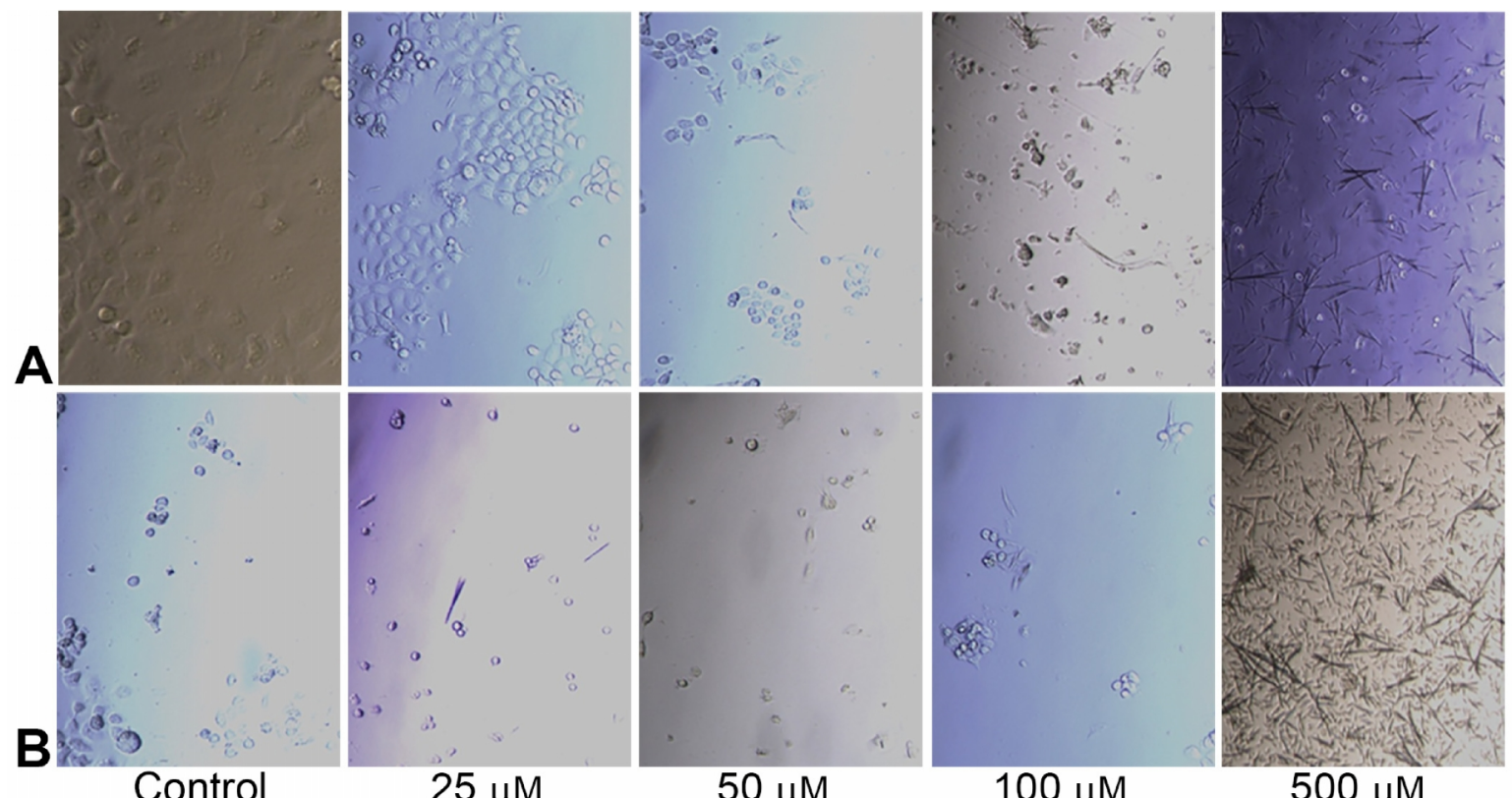

Figure 2. Morphological changes of HN5 cells after treatment with different concentrations of wogonin alone (A) or with exposure to 2 Gy radiation dose (B). HN5 cells were incubated with various concentrations of wogonin (25-500 $\mu \mathrm{M})$ for 72 hours (A). In combination therapy, HN5 cells were incubated with different concentrations of wogonin $(25-500 \mu \mathrm{M})$ for 6 hours. Then the cells received 2 Gy radiation dose and incubated more 66 hours (B).

\subsection{The effect of the continuance or elimination of wogonin during radiotherapy}

Investigation on the effect of the continuance or elimination of wogonin during radiotherapy revealed that at all concentrations of wogonin $(25-500 \mu \mathrm{M})$ radiation along with the drug, reduced cell viability more significantly. In high concentrations of 100 and $500 \mu \mathrm{M}$, the effects of presence of wogonin on cell viability were significant $(\mathrm{p}<0.001)$ in both situations (Figure 3$)$.

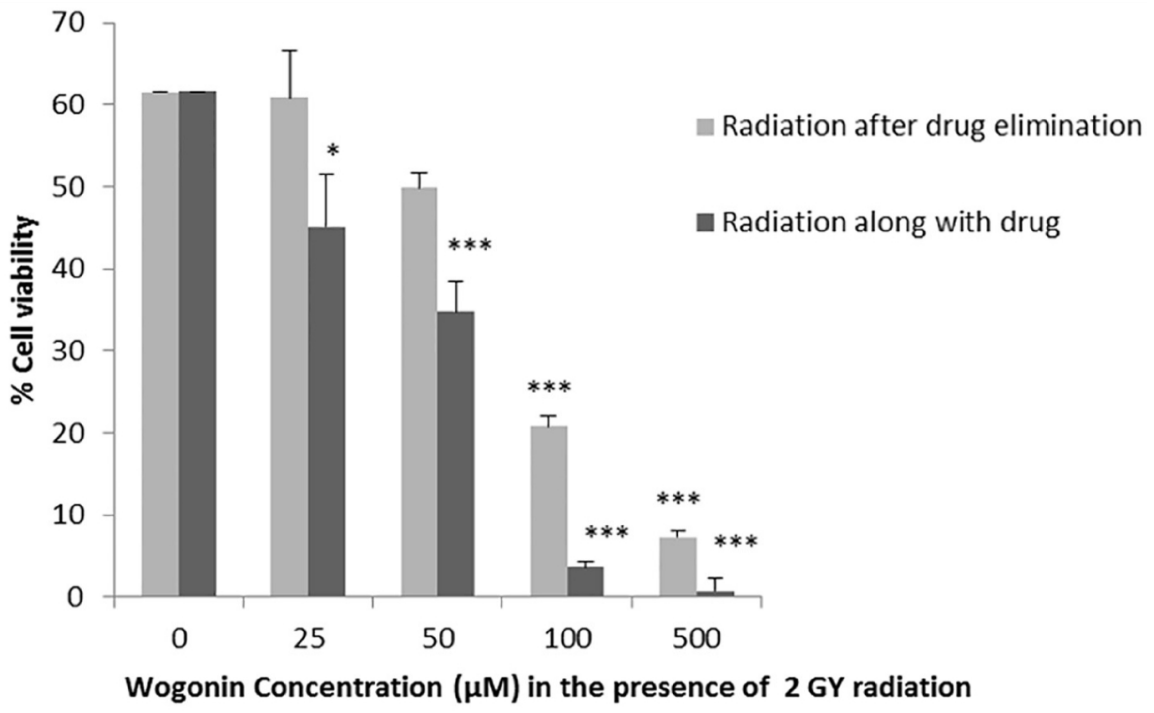

Figure 3. The effects of wogonin elimination during radiotherapy. HN5 cells were incubated with various concentrations of wogonin $(25-500 \mu \mathrm{M})$ for 48 hours. Then after wogonin elimination in one group, both groups received $2 \mathrm{~Gy}$ radiation dose. After a further 66 hours' incubation, cell viability was determined by MTT assay;

$$
* \mathrm{p}<0.05, * * * \mathrm{p}<0.001)
$$

\subsection{Effects of coincident radiotherapy and wogonin on cell viability HN5}

For investigation into the effects of different doses of radiotherapy and wogonin on cell viability HN5, the concentration of $100 \mu \mathrm{M}$ of wogonin was chosen based on previous steps (Figure 3). The cells were incubated with 
$100 \mu \mathrm{M}$ of wogonin for 6 hours. Afterward it was affected by 2-10 Gy $\gamma$-rays and then incubated for 66 hours. As shown in Figure 4, wogonin could sensitize cells to radiation-induced toxicity. At lower dose of radiation (2-4 Gy) the radiosensitizer effects of wogonin was more observable and these combination therapies reduced cell viability significantly $(\mathrm{p}<0.001$ and $\mathrm{p}<0.01$ respectively). In other words, wogonin increased radiation sensitivity and cell death. The effects of combination therapy compared to either wogonin or radiation alone have been better exhibited in Figure 5. As one can see, combination therapy of $100 \mu \mathrm{M}$ wogonin and 2 Gy radiation (compared to each of wogonin or radiation alone) reduced cell viability significantly $(\mathrm{p}<0.01$ and $\mathrm{p}<0.001$ respectively).

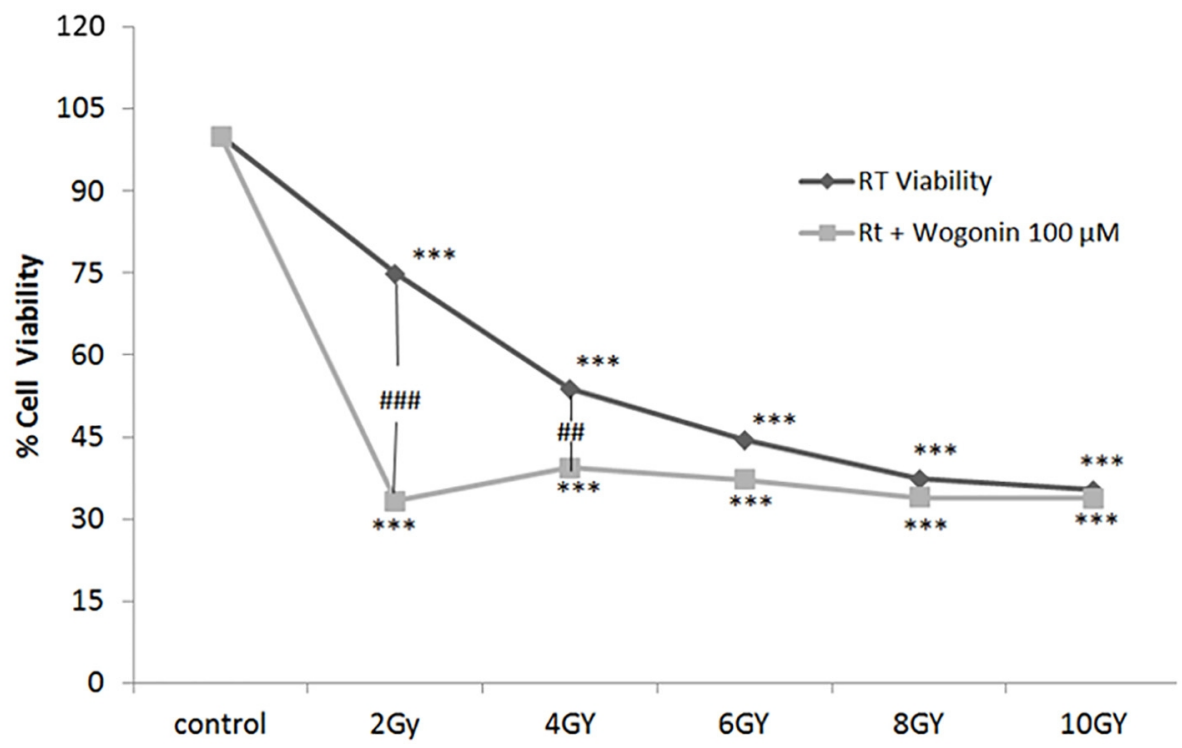

Figure 4. Comparison of the wogonin effects in different radiation doses. HN5 cells were incubated with $100 \mu \mathrm{M}$ concentration of wogonin for 6 hours. Then the cells received 2-10 Gy radiation dose. After a further 66 hours' incubation, cell viability was determined by MTT method. Statistical differences have been shown as $* * * p<0.001$ when compared with the control group and ${ }^{\# \#} \mathrm{p}<0.01$ and ${ }^{\# \#} \mathrm{p}<0.001$ in comparison of two wogonin treated and untreated groups.

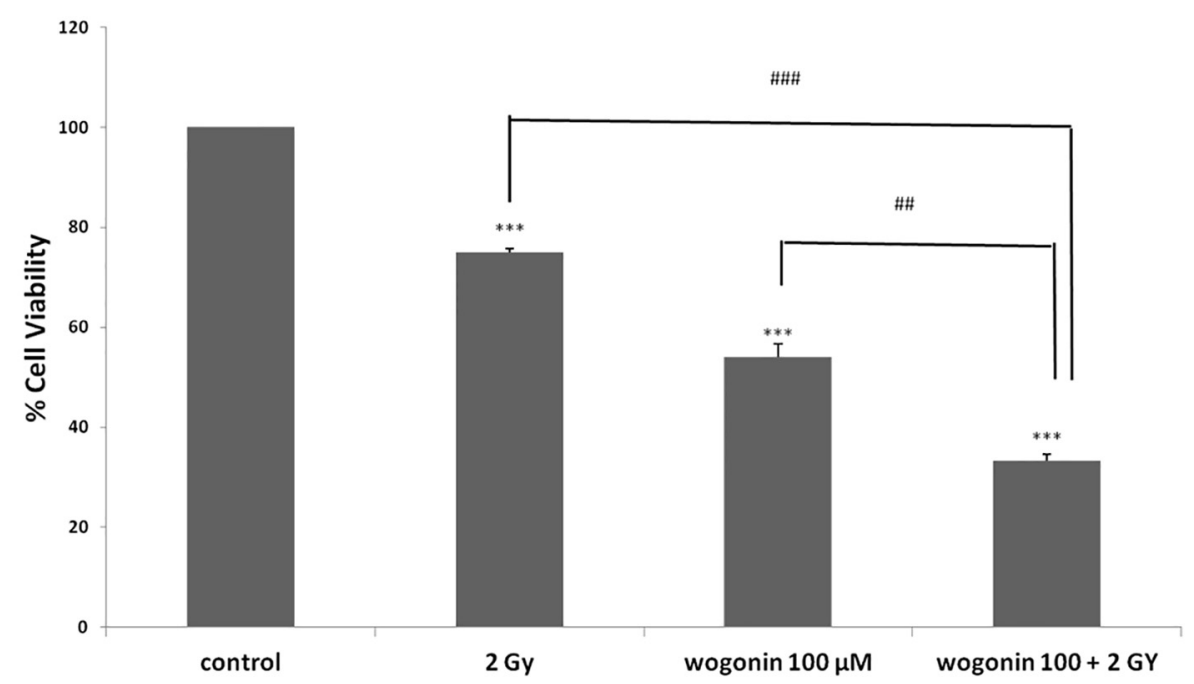

Figure 5. Comparison of the effects of wogonin $(100 \mu \mathrm{M})$ and 2 Gy irradiation and combination therapy. HN5 cells were incubated with wogonin $(100 \mu \mathrm{M})$ for 6 hours. Then the cells received 2Gy radiation dose. After a further 66 hours' incubation, cell viability was determined by MTT method. The 2 Gy irradiated group did not receive any wogonin; the wogonin treaded group was incubated with $100 \mu \mathrm{M}$ wogonin for 72 hours $(6+66 \mathrm{~h})$ without any irradiation. Untreated cells considered as the control group. Statistical differences have been shown as $* * * p<0.001$ when compared with the control group and ${ }^{\# \#} \mathrm{p}<0.01$ and ${ }^{\# \#} \mathrm{p}<0.001$ in comparison to the combination treated group. 


\section{Discussion}

Cancer is a major health difficulty worldwide. Natural compounds have been used to prevent and treat cancer for a long time. Thus they are appropriate for the development of anti-cancer drugs (19). Anti-tumor drugs are known to regulate cell cycle progression, inhibit cell proliferation, and induce apoptosis in cancer cells (20). The two main ways to prevent tumor growth and progression include, induction of cell death and inhibition of cell growth $(21,22)$. The dried root of Scutellaria from the Lamiaceae family is a widely used Chinese herbal medicine that historically is used in anti-inflammatory and anticancer therapy (23-27). The bioactive components of the Scutellaria species have been confirmed to be flavones (28). Wogonin is one of the major flavones of Scutellaria litwinowii that induces apoptosis in tumoral cells via different pathways (29). The antitumor functions of these flavones are largely due to their abilities to upregulation of intracellular reactive oxygen species (ROS), to attenuate NF- $\mathrm{KB}$ activity to inhibit several genes important for regulation of the cell cycle, to suppress COX-2 gene expression and to prevent viral infections. Wogonin can also target PI3k/AKT and MAPk pathways (30). On the other hand, some studies have been shown that wogonin has tumor-selectivity. This tumor-selectivity might be due to presence of more $\mathrm{O}_{2}{ }^{-}$in tumor cells, so wogonin causes more $\mathrm{H}_{2} \mathrm{O}_{2}$ production in tumoral cells compared to normal cells (8). Susan Shojaee et al. demonstrated S. litwinowii root extract protected normal cells against DNA damage caused by $\mathrm{H}_{2} \mathrm{O}_{2}$. They noted flavonoids may impart in this effect by scavenging free radicals (31). In an earlier study, Najarani et al. showed that wogonin had an anti-cancer effect on Hela cell line (13). The effects of wogonin as a chemosensitizer has been studied too. Wogonin acted as a chemosensitizer in combination with Etoposide, TNF- $\alpha$ and TRAIL, 5-FU, Cisplatin and Doxorubicin (30). There is no study on the radiosensitizer effect of wogonin.

Concomitant use of chemotherapeutic agents and radiotherapy on radiosensitivity in head and neck cancers has been investigated in some studies. Torres et al. studied the effects of AC480, a pan-HER inhibitor, combined with radiation on head and neck cancer. They found that the drug significantly enhanced the in vitro radio sensitivity of $\mathrm{HN}-5$ cell lines (18). Luka Milas et al. studied the effects of the drug (C225 antibody) when combined with radiation on head and neck cancer. They reported that the drug enhanced the response of these cells to radiation in vivo; the enhancement was attributed to increased radiation-induced apoptosis (32). In another study, Sano et al. showed that vandetanib restores head and neck cancer cells sensitivity to cisplatin and radiation. They found that vandetanib and cisplatin effectively radiosensitized head and neck squamous cell carcinoma both in vitro and in vivo (33).

Since no information is available on the effects of wogonin combined with radiotherapy, in this study we investigated the effects of wogonin in combination with radiotherapy on head and neck cancer cells for the first time. For this purpose, at the first step, the effect of this flavonoid on induction of cell death and inhibition of cell growth on head and neck cancer cells was evaluated. Cells were exposed to increasing concentration of wogonin for 24,48 , and 72 hours, and cell viability was quantified by MTT assay. Our results confirmed that wogonin derived from Scutellaria litwinowii has anti-proliferation and anti-carcinogenic activities. Cell viability in the $\mathrm{HN}-5$ cell line decreased after exposure to wogonin in a time- and concentration-dependent manner.

At the next step, the effects of wogonin combined with radiation on HN-5 cell line were determined. Our study confirmed that concomitant use of the drug (wogonin) and radiation on HN-5 cell line increases radio sensitivity and cell death. We demonstrated that at the presence of 2 Gy radiation, cell viability reduced by increasing the dose of the wogonin and keeping it during radiation. The concentration of $100 \mu \mathrm{M}$ wogonin was chosen as the best wogonin concentration for future studies because of its acceptable cytotoxic effects. Wogonin in this concentration reduced cell survival significantly, but was not too toxic to hide radiosensitizing effects. On the other hand, the results demonstrated the best radiation dose to reveal the radiosensitizing effect of $100 \mu \mathrm{M}$ wogonin was $2 \mathrm{~Gy}$; this effect was not observable by radiation dose increasing, due to high cell cytotoxicity.

Some studies declared that wogonin in the concentration range of 10-100 $\mu \mathrm{M}$ induces apoptosis in many cancer cells without any toxicity on normal cells (30). The protective effects of wogonin have been demonstrated in some normal cells $(31,34)$. In this study, we confirmed the cytotoxic effects of wogonin on HN-5 cells in these concentrations. Furthermore, we demonstrated the radiosensitizer effects of wogonin on these cancer cells at 100 $\mu \mathrm{M}$ concentration. For better commenting on the use of wogonin as a radiosensitizer, we need to study the radioprotective effects of wogonin on normal cells too. Considering the various mechanisms that are mentioned for the effects of wogonin on cancer cells, the diagnosis of the possible mechanisms for the radiosensitizer effects of wogonin should be further investigated. 


\section{Conclusions}

Concurrent use of wogonin and radiation, increased radiation sensitivity and cell death in HN5 cancer cells. Therefore, wogonin can be well considered as a potential sensitizer in cancer treatment. For this purpose protective effects of wogonin on normal cells must be investigated in future.

\section{Acknowledgments:}

Authors are thankful to Dr. Zahra Tayarani et al. (Herbarium of the Ferdowsi University of Mashhad) for the extraction, isolation and purification of wogonin from Scutellaria litwinowii roots. This report has been extracted from the MSc thesis of Zahra Nariman (Grant number: 920003). The authors would also like to thank the Research Affairs of Mashhad University of Medical Sciences, Mashhad, Iran.

\section{Conflict of Interest:}

There is no conflict of interest to be declared.

Authors' contributions:

All authors contributed to this project and article equally. All authors read and approved the final manuscript.

\section{References:}

1) Joshi P, Dutta S, Chaturvedi P, Nair S. Head and neck cancers in developing countries. Rambam Maimonides medical journal. 2014; 5(2): e0009. doi: 10.5041/RMMJ.10143. PMID: 24808947, PMCID: PMC4011474.

2) Mirzaei M, Hosseini S-A, Ghoncheh M, Soheilipour F, Soltani S, Soheilipour F, et al. Epidemiology and trend of head and neck cancers in Iran. Global journal of health science. 2016; 8(1): 189. PMID: 26234980, PMCID: PMC4803954.

3) Sanderson R, Ironside J. Squamous cell carcinomas of the head and neck. BMJ: British Medical Journal. 2002; 325(7368): 822-827. PMID: 12376446, PMCID: PMC1124330.

4) Singh B, Kim SH, Carew JF, Yu I, Shaha AR, Wolden S, et al. Genome-wide screening for radiation response factors in head and neck cancer. The Laryngoscope. 2000; 110(8): 1251-6. doi: 10.1097/00005537-200008000-00005. PMID: 10942121.

5) Simstein R, Burow M, Parker A, Weldon C, Beckman B. Apoptosis, chemoresistance, and breast cancer: insights from the MCF-7 cell model system. Experimental biology and medicine. 2003; 228(9): 995-1003. PMID: 14530507.

6) Liauw SL, Connell PP, Weichselbaum RR. New paradigms and future challenges in radiation oncology: an update of biological targets and technology. Science translational medicine. 2013; 5(173): 173sr2-sr2. doi: 10.1126/scitranslmed.3005148. PMID: 23427246, PMCID: PMC3769139.

7) Tai MC, Tsang SY, Chang LY, Xue H. Therapeutic potential of wogonin: a naturally occurring flavonoid. CNS drug reviews. 2005 Summer; 11(2): 141-50. PMID: 16007236.

8) Li-Weber M. New therapeutic aspects of flavones: the anticancer properties of Scutellaria and its main active constituents Wogonin, Baicalein and Baicalin. Cancer treatment reviews. 2009 Feb; 35(1): 57-68. doi: 10.1016/j.ctrv.2008.09.005. PMID: 19004559.

9) Himeji M, Ohtsuki T, Fukazawa H, Tanaka M, Yazaki S, Ui S, et al. Difference of growth-inhibitory effect of Scutellaria baicalensis-producing flavonoid wogonin among human cancer cells and normal diploid cell. Cancer letters. 2007 Jan 245(1-2): 269-74. doi: 10.1016/j.canlet.2006.01.011. PMID: 16497434.

10) Polier G, Ding J, Konkimalla BV, Eick D, Ribeiro N, Kohler R, et al. Wogonin and related natural flavones are inhibitors of CDK9 that induce apoptosis in cancer cells by transcriptional suppression of Mcl-1. Cell death \& disease. 2011 Jul 21; 2: e182. doi: 10.1038/cddis.2011.66. PMID: 21776020, PMCID: PMC3199715.

11) Chung H, Jung YM, Shin DH, Lee JY, Oh MY, Kim HJ, et al. Anticancer effects of wogonin in both estrogen receptor-positive and -negative human breast cancer cell lines in vitro and in nude mice xenografts. International journal of cancer. 2008; 122(4): 816-22. doi: 10.1002/ijc.23182. PMID: 17957784.

12) Lee DH, Kim C, Zhang L, Lee YJ. Role of p53, PUMA, and Bax in wogonin-induced apoptosis in human cancer cells. Biochemical pharmacology. 2008; 75(10): 2020-33. doi: 10.1016/j.bcp.2008.02.023. PMID: 18377871, PMCID: PMC2424318. 
13) Tayarani-Najarani Z, Asili J, Parsaee H, Mousavi SH, Mashhadian NV, Mirzaee A, et al. Wogonin and neobaicalein from Scutellaria litwinowii roots are apoptotic for HeLa cells. Rev. bras. farmacogn. 2012; 22(2): 268-76. doi: 10.1590/S0102-695X2011005000161.

14) Dayal R, Singh A, Pandey A, Mishra KP. Reactive oxygen species as mediator of tumor radiosensitivity. Journal of cancer research and therapeutics. 2014; 10(4): 811-8. doi: 10.4103/0973-1482.146073. PMID: 25579513.

15) Cole IB, Cao J, Alan AR, Saxena PK, Murch SJ. Comparisons of Scutellaria baicalensis, Scutellaria lateriflora and Scutellaria racemosa: genome size, antioxidant potential and phytochemistry. Planta medica. 2008; 74(04): 474-81. doi: 10.1055/s-2008-1034358. PMID: 18484546.

16) Mousavi SH, Tavakkol-Afshari J, Brook A, Jafari-Anarkooli I. Role of caspases and Bax protein in saffroninduced apoptosis in MCF-7 cells. Food and chemical toxicology : an international journal published for the British Industrial Biological Research Association. 2009; 47(8): 1909-13. doi: 10.1016/j.fct.2009.05.017. PMID: 19457443.

17) Magne N, Fischel JL, Dubreuil A, Formento P, Marcie S, Lagrange JL, et al. Sequence-dependent effects of ZD1839 ('Iressa') in combination with cytotoxic treatment in human head and neck cancer. British journal of cancer. 2002; 86(5): 819-27. doi: 10.1038/sj.bjc.6600103. PMID: 11875748.

18) Torres MA, Raju U, Molkentine D, Riesterer O, Milas L, Ang KK. AC480, formerly BMS-599626, a pan Her inhibitor, enhances radiosensitivity and radioresponse of head and neck squamous cell carcinoma cells in vitro and in vivo. Investigational new drugs. 2011; 29(4): 554-61. doi: 10.1007/s10637-010-9389-3. PMID: 20119866.

19) Da Rocha AB, Lopes RM, Schwartsmann G. Natural products in anticancer therapy. Current Opinion in Pharmacology. 2001; 1(4): 364-9. PMID: 11710734.

20) Hseu YC, Chen SC, Chen HC, Liao JW, Yang HL. Antrodia camphorata inhibits proliferation of human breast cancer cells in vitro and in vivo. Food and chemical toxicology : an international journal published for the British Industrial Biological Research Association. 2008; 46(8): 2680-8. doi: 10.1016/j.fct.2008.04.036. PMID: 18550246.

21) Huang P, Feng L, Oldham EA, Keating MJ, Plunkett W. Superoxide dismutase as a target for the selective killing of cancer cells. Nature. 2000; 407(6802): 390-5. doi: 10.1038/35030140. PMID: 11014196.

22) Zhang L, Tao L, Ruan J, Li W, Wu Y, Yan L, et al. Xanthatin induces G2/M cell cycle arrest and apoptosis in human gastric carcinoma MKN-45 cells. Planta medica. 2012; 78(9): 890-5. doi: 10.1055/s-00311298481. PMID: 22532019.

23) Burnett BP, Jia Q, Zhao Y, Levy RM. A medicinal extract of Scutellaria baicalensis and Acacia catechu acts as a dual inhibitor of cyclooxygenase and 5-lipoxygenase to reduce inflammation. Journal of medicinal food. 2007; 10(3): 442-51. doi: 10.1089/jmf.2006.255. PMID: 17887937.

24) Parajuli P, Joshee N, Rimando AM, Mittal S, Yadav AK. In vitro antitumor mechanisms of various Scutellaria extracts and constituent flavonoids. Planta medica. 2009; 75(1): 41-8. doi: 10.1055/s-00281088364. PMID: 19031366.

25) Zhang Y, Wang X, Wang X, Xu Z, Liu Z, Ni Q, et al. Protective effect of flavonoids from Scutellaria baicalensis Georgi on cerebral ischemia injury. Journal of ethnopharmacology. 2006; 108(3): 355-60. doi: 10.1016/j.jep.2006.05.022. PMID: 16829002.

26) Ye F, Wang H, Jiang S, Wu J, Shao J, Cheng X, et al. Quality evaluation of commercial extracts of Scutellaria baicalensis. Nutrition and cancer. 2004; 49(2): 217-22. doi: 10.1207/s15327914nc4902_14. PMID: 15489215.

27) Sonoda M, Nishiyama T, Matsukawa Y, Moriyasu M. Cytotoxic activities of flavonoids from two Scutellaria plants in Chinese medicine. Journal of ethnopharmacology. 2004; 91(1): 65-8. doi: 10.1016/j.jep.2003.11.014. PMID: 15036470.

28) Malikov V, Yuldashev M. Phenolic compounds of plants of the Scutellaria L. genus. Distribution, structure, and properties. Chem. Nat. Compd. 2002; 38(4): 358-406.

29) Tayarani-Najaran Z, Mousavi SH, Vahdati-Mashhadian N, Emami SA, Parsaee H. Scutellaria litwinowii induces apoptosis through both extrinsic and intrinsic apoptotic pathways in human promyelocytic leukemia cells. Nutrition and cancer. 2012; 64(1): 80-8. doi: 10.1080/01635581.2012.630162. PMID: 22098153.

30) Sharma N, Singh AK, Sodhi SS, ZHANG J-J, Mongre RK, Ghosh M, et al. Anti-tumor activity of wogonin, an extract from Scutellaria baicalensis, through regulating different signaling pathways. Chinese Journal of Natural Medicines. 2017; 15(1): 15-40. doi: 10.1016/S1875-5364(17)30005-5. PMID: 28259249. 
31) Shojaee S, Parhiz H, Eshaghi A, Emami SA, Asili J, Behravan J, et al. In vitro protective effects of Scutellaria litwinowii root extract against $\mathrm{H} 2 \mathrm{O} 2$-induced DNA damage and cytotoxicity. Journal of Complementary and Integrative Medicine. 2014; 11(2): 121-7. doi: 10.1515/jcim-2014-0009. PMID: 24731956.

32) Milas L, Mason K, Hunter N, Petersen S, Yamakawa M, Ang K, et al. In vivo enhancement of tumor radioresponse by $\mathrm{C} 225$ antiepidermal growth factor receptor antibody. Clinical cancer research : an official journal of the American Association for Cancer Research. 2000; 6(2): 701-8. PMID: 10690556.

33) Sano D, Matsumoto F, Valdecanas DR, Zhao M, Molkentine DP, Takahashi Y, et al. Vandetanib restores head and neck squamous cell carcinoma cells' sensitivity to cisplatin and radiation in vivo and in vitro. Clinical cancer research : an official journal of the American Association for Cancer Research. 2011; 17(7): 1815-27. doi: 10.1158/1078-0432.CCR-10-2120. PMID: 21350000. PMCID: PMC3074405.

34) Afsharzadeh M, Tayarani-Najaran Z, Zare A, Mousavi SH. Protective effect of Scutellaria litwinowii extract on serum/glucose-deprived cultured PC12 cells and determining the role of reactive oxygen species. Journal of toxicology. 2012; 2012. doi: 10.1155/2012/413279. PMID: 22888343, PMCID: PMC3409551. 